Journal of Social Sciences 4 (3): 229-236, 2008

ISSN 1549-3652

(C) 2008 Science Publications

\title{
Participation and Decision Making Role of Rural Women in Economic Activities: A Comparative Study for Members and Non-Members of the Micro-Credit Organizations in Bangladesh
}

\author{
${ }^{1}$ Mahmuda Hoque and ${ }^{2}$ Yoshihito Itohara \\ ${ }^{1}$ Doctoral Student, The United Graduate School of Agricultural Sciences, Tottori University, Japan \\ ${ }^{2}$ Professor, Faculty of Agriculture, Yamaguchi University, Japan
}

\begin{abstract}
The study was aimed to know the present status of rural women's participation and decision making role in economic activities (called EAs from here) in Bangladesh. The sample of the study consisted of 92 farm women from Rampur village of Palashbari upazila under Gaibandha district. Necessary data for the study were collected with questionnaire by personal interviewing of the respondent women covering all types of farm families (i.e., landless, marginal, small, medium and large). Result showed that among the agricultural activities rural women's participation was relatively higher in various post harvest activities and livestock management activities than other agricultural activities. On the other side, their participation was almost nil in the case of aquaculture activities while few of them participate in some selected non-agricultural activities like handicrafts making, tailoring and Nakshi katha making. It was also evident from the study that farm women were contributing in household income through participating in EAs. The result of the study explored that woman's personal income, institutional participation and training received by the women are the most influential factors for increasing the extent of participation of women in EAs. Findings also showed that in most of the cases women's participation in decision making process regarding various family affairs is lower than their male counter part. However, both in participation in EAs and decision making process NGO women were in the leading edge than the Non-NGO women.
\end{abstract}

Key words: Participation, decision making role, economic activities (EAs), micro-credit organizations, rural women

\section{INTRODUCTION}

Women have made important contributions in almost every aspects of our society from the time immemorial. About half (49\%) of the population of Bangladesh is women among them 45.6 percent are associated with the farming community ${ }^{[1]}$. Historically the work of women in Bangladesh was mostly confined to the homestead due to the culture, religion and social restrictions. However, with the great declining of the socio-economic situation of the country the women are breaking through the traditional norms and coming forward to participate in the development activities outside their homestead Currently, women in Bangladesh have an anchoring role in the management of their families as well as equal participation in different EAs like crop production, post-harvest activities, poultry rearing, management of livestock and fisheries, pisciculture and miscellaneous income generating activities ${ }^{[2] .}$ Especially in the rural areas resource poor households' women's participation in income generating activities is high because these households have higher number of family members in compare to lower number of capable male earning members. They are intimately involved in all phases of agricultural activities: from sowing seeds to harvesting and processing of crops. They are also involved in different EAs like sewing dress, making baskets, making papers, flower vases, rearing of poultry, livestock and in different small scale business. Even women from the poorest households sometimes work outside the home as paid laborers for their family survival $^{[3]}$.

Though, Bangladeshi women are playing very important role in both at home and outside but still disparities exist between men and women in education, health, employment and income opportunities, control over assets, personal security and participation in the political process. 
J. Social Sci., 4 (3): 229-236, 2008

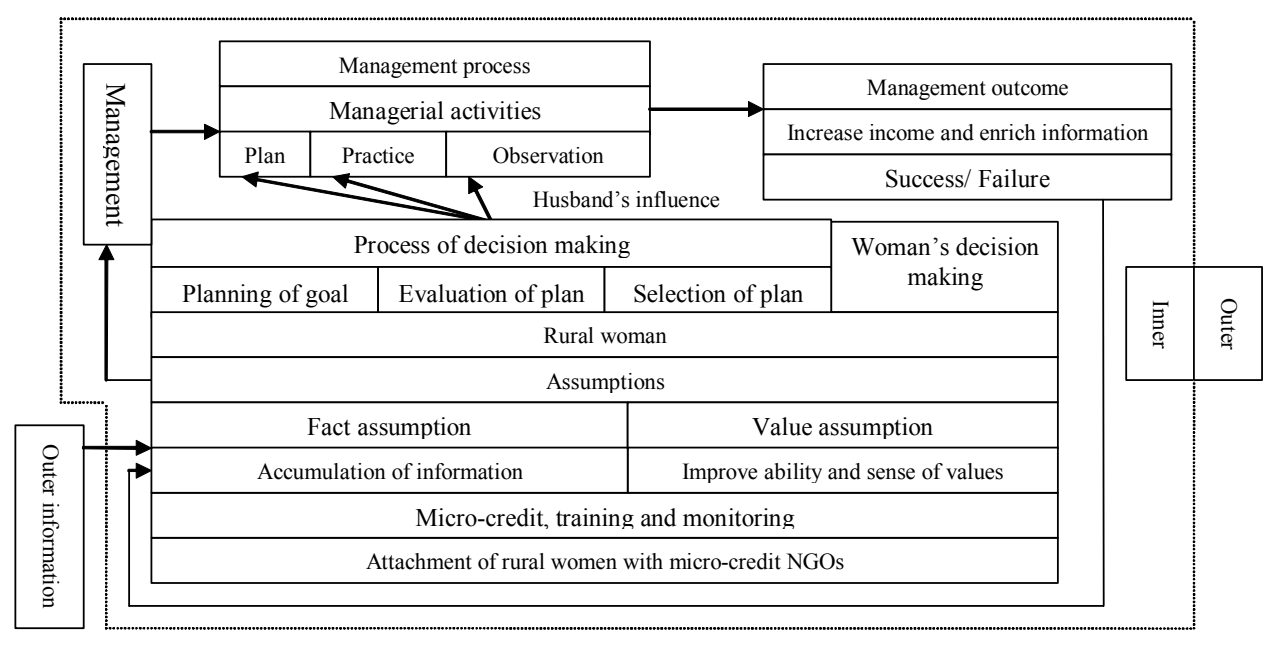

Fig. 1: Conceptual framework of the study

In reality, according to the United Nations Genderrelated Development Index (GDI), Bangladesh ranked 105 th out of 177 countries globally ${ }^{[4]}$. Therefore, Bangladeshi women are underprivileged and less empowered and this undeniably restricts the country's ability to achieve its full potential.

Considering this reality our development partners and the donor agencies prescribed to involve the women in all sorts of activities for reducing gender inequalities and empowering them to achieve sustainable development. Thus the government has also included women empowerment issue in the Millennium Development Goal. In addition, for improving the empowerment of women a number of measures have been taken by the micro-credit NGOs like Grameen Bank (GB), Bangladesh Rural Advancement Committee (BRAC), PROSHIKA, Thengamara Mohila Sabuj Sangha (TMSS) and Rangpur Dinajpur Rural Service (RDRS) etc. All these micro-credit NGOs are giving support to the deprived section of the society, especially women, in terms of employment, income earning to improve their status of livings through the services like small loans, education for their children, health and family planning care, sanitation, legal support and various types of skill development training ${ }^{[5]}$. It is understandable from Figure 1 that, due to the direct and indirect support from these microcredit NGOs the capabilities of the involved women are increasing day by day that motivates them to participate in various EAs which eventually contribute in their household income.

As, participation in EAs and decision making role of women regarding family issues are the important indicator of their empowerment, so an attempt has been made to study with an aim to know the level of participation of women of Gaibandha district in various EAs along with their socio-economic status and their role in the family decision making process.

Objectives of the Study: The study was aimed with the following specific objectives:

- To determine the present level of participation of rural women in different EAs as well as to explore the factors related to extent of participation in EAs

- To assess how the women's participation in EAs are related to their household income

- To verify the role of the rural women in the decision making process regarding various family affairs

\section{MATERIALS AND METHODS}

The practical data for the study was collected from 92 farm women of Rampur village of Palashbari upazila (sub-district) under Gaibandha district from May 10 to June 07,2006 . The respondent farm women were taken from all categories of farm families like landless farmers, marginal farmers, small farmers, medium farmers and large farmers based on their land holdings. Sample from each group were taken according to the proportion (percentage of total number of farm women living the study village) as stated in Agricultural Extension Manual prepared by Department of Agricultural Extension (DAE) ${ }^{[6]}$. Among the respondent farm women all the women from landless and marginal families and 10 women from small farm families were the members of micro-credit organizations like 
Grameen Bank (GB), Bangladesh Rural Advancement Committee (BRAC) and Thengamara Mohila Sabuj Sangha (TMSS). To know the status of participation in EAs of the women 33 activities (covering crop production, livestock production, aquaculture and nonagricultural activities) were included in the questionnaire.

The extent of participation in EAs by a farm woman was rated on the extent of a woman's involvement in all of the selected 10 EAs. Respondents were asked to what extent they were involved with these 10 EAs. A 4-point rating scale was used to measure the extent of participation in EAs by the women. They were asked the frequency of their participation is frequently, occasionally, seldom or never. Points were awarded for each response, with sufficient scoring as the frequent to no participation (3, 2,1 and 0 respectively). A respondent's score could range from 0 to 30 , where 0 indicated never participation and 30 indicated the highest participation in EAs. Frequency counts of responses were also recorded to compute the Participation Index (PI) of a woman for each of the EA. Participation Index of EAs was computed by using the following formula:

Where:

$$
\mathrm{PI}=\left(\mathrm{N}_{1} \mathrm{X} 3\right)+\left(\mathrm{N}_{2} \mathrm{X} 2\right)+\left(\mathrm{N}_{3} \mathrm{X} 1\right)+\left(\mathrm{N}_{4} \mathrm{X} 0\right)
$$

PI = Participation Index of EAs

$\mathrm{N}_{1}=$ Number of women who participate in the EA frequently

$\mathrm{N}_{2}=$ Number of women who participate in the EA occasionally

$\mathrm{N}_{3}=$ Number of women who participate in the EA seldom

$\mathrm{N}_{4}=$ Number of women who never participate in the EA

Finally, collected data were tabulated and further analyzed with the software SPSS 12.0 version.
Descriptive statistics (i.e., mean, standard deviation, percentage, rank order etc.), paired-t test, multiple regression analysis and chi-square $\left(\chi^{2}\right)$ tests were used in the study.

\section{RESULTS AND DISCUSSION}

Socio-economic profile of the respondent women: The salient features of the nine selected characteristics of the respondent women are shown in Table 1. The result of t-test for the difference of means has also been shown in the Table 1. As the respondent farm women were selected from all categories of farm families thus excluding their age there is a significant differences in their socio-economic profile. Findings of the study show that Non-NGO women are in better situation in respect of education and family land holdings due to their better family background compare to their counter part NGO women.

On the contrary, NGO women are significantly ahead in respect of personal income, training received, monitoring by credit provider NGOs and in the case of institutional participation due to their intimate involvement with the micro-credit NGOs in compare to the Non-NGO women.

Women's participation in EAs and their personal income: The main objective of the study was to know the status of participation of farm women in different EAs thus the information related to this objective has been shown in the Table 2. As, Bangladesh is an agrarian country so agricultural activities are treated as the major EAs in rural areas. The findings of the study show that women in Bangladesh participate to some extent in various agricultural activities. However, their participation is relatively in post-harvest activities than pre-harvest activities. Probably this is due to the fact of division of labour between man and women in a family.

Table 1: Salient features of the respondent farm women $(\mathrm{N}=92)$

\begin{tabular}{|c|c|c|c|c|c|c|}
\hline \multirow[b]{2}{*}{ Variables } & \multirow[b]{2}{*}{ Measures } & \multicolumn{2}{|c|}{ NGO women $(n=46)$} & \multicolumn{2}{|c|}{ Non-NGO women $(n=46)$} & \multirow[t]{2}{*}{ t- statistics } \\
\hline & & Mean & Std. dev & Mean & Std. dev. & \\
\hline Age & Years & 35.78 & 7.37 & 37.30 & 10.96 & -0.975 \\
\hline Educational level & Level & 2.76 & 2.95 & 5.93 & 3.0 & $-5.104 * *$ \\
\hline Family land holdings & Hectares & 0.122 & 0.204 & 1.26 & 1.0 & $-8.491 * *$ \\
\hline Woman's personal income & ‘000’ BDT & 7.49 & 2.89 & 6.31 & 2.25 & $2.409 * *$ \\
\hline Household income & '000’ BDT & 42.20 & 14.79 & 44.35 & 13.14 & -0.785 \\
\hline Training received & No. of days & 1.59 & 1.9 & 0.17 & 0.53 & $4.650 * *$ \\
\hline Credit received & 000’ BDTaka & 15.0 & 7.78 & 8.0 & 0.83 & $13.448 * *$ \\
\hline Monitoring by credit provider NGO & $1=$ Yes $0=$ Otherwise & 1.0 & 0.00 & 0.09 & .28 & $21.74 * *$ \\
\hline Institutional participation & $1=$ Yes, $0=$ Otherwise & 1.0 & 0.00 & 0.28 & 0.46 & $10.68 * *$ \\
\hline
\end{tabular}

*: 1000 Bangladeshi Taka (BDT)=14.57 US \$; Source: Authors' Survey 
J. Social Sci., 4 (3): 229-236, 2008

Table 2: Summary of women's participation in various EAs

\begin{tabular}{|c|c|c|c|c|c|c|c|c|c|}
\hline \multirow[b]{3}{*}{ EAs } & \multicolumn{8}{|c|}{ Number of women's participation in EAs } & \multirow[b]{3}{*}{ t-statistics } \\
\hline & \multicolumn{4}{|c|}{ NGO women $(n=46)$} & \multicolumn{4}{|c|}{ Non-NGO women $(\mathrm{n}=46)$} & \\
\hline & No & Rare & Occasional & Frequent & No & Rare & Occasional & Frequent & \\
\hline Crop production (pre-harvest) activities & 32 & 13 & 1 & 0 & 41 & 4 & 1 & 0 & $2.029^{*}$ \\
\hline Crop production (post-harvest activities) & 0 & 1 & 21 & 24 & 3 & 3 & 25 & 15 & $2.573^{*}$ \\
\hline Home gardening & 0 & 8 & 34 & 4 & 5 & 8 & 30 & 3 & 1.756 \\
\hline Poultry management & 2 & 14 & 24 & 6 & 7 & 16 & 22 & 1 & $2.514^{*}$ \\
\hline Goat rearing & 11 & 13 & 20 & 2 & 36 & 9 & 1 & 0 & $6.859 * *$ \\
\hline Cattle rearing & 18 & 19 & 7 & 2 & 33 & 9 & 4 & 0 & $3.158 * *$ \\
\hline Aquaculture activities & 41 & 5 & 0 & 0 & 44 & 2 & 0 & 0 & 1.138 \\
\hline Marketing activities & 32 & 12 & 2 & 0 & 44 & 2 & 0 & 0 & $3.490 * *$ \\
\hline Wage labour & 36 & 6 & 4 & 0 & 46 & 0 & 0 & 0 & $3.288^{* *}$ \\
\hline Non-agricultural activities & 23 & 13 & 9 & 1 & 33 & 8 & 3 & 2 & 1.708 \\
\hline
\end{tabular}

Moreover, women in Bangladesh always remain at home due to social custom that might be another reason of their more participation in post-harvest activities rather than pre-harvest. Table 2 also exhibits that NGO women participate more both in pre and post harvest activities compare to Non-NGO women.

The results of the study show that rural women's participation is relatively higher in livestock related activities (i.e., poultry, goat and cattle management) rather than crop production and aquaculture activities. Likewise, crop production activities NGO women are also ahead in goat, cattle and poultry management activities compare to their counter part Non-NGO women.

While, both group of women equally participate in home gardening activities. This is due to the reason that traditionally all homesteads in Bangladesh have a kitchen garden for growing different types of vegetables especially for family consumption and sometimes they sell some surplus vegetables after meeting their family need.

The above table also shows that in Bangladesh both group of women's participation is least in aquaculture activities. A study of Rahman and Naoroze also supports the same that the common level of women's participation in aquaculture activities remains far below the expectation ${ }^{[7]}$. On the other hand, findings show that a few of the NGO women works as wage labour while Non-NGO women never works as wage labour. This is due to the reason that NGO women are the members of poor farm families that usually suffer from frequent economic and food crisis and bound them to work as wage labour for their family survival. Like wage labour few NGO women actively participate in some marketing related activities where as, Non-NGO women's participation is very insignificant in this activity.
Like other agricultural activities women's participation in various non-agricultural activities (i.e., like tailoring, handicrafts making, preparation of bamboo and cane materials) are increasing day by day in Bangladesh. The results of the study also show that a significant portion of women from both group participate to some extent in this type of activities. In study of Centre for Policy Dialogue (CPD) also reported that Bangladeshi women's adoption of various non-agricultural activities is increasing in the recent time ${ }^{[8]}$.

However, another important focus of the study was to verify whether these sorts of participation of women in EAs have any significant influence on women's personal income or not. Thus, further initiative was made to asses the amount of income earned personally by the respondent women through participation in the selected EAs and the data were presented in Table 3.

The above Table 3 shows that women in Bangladesh personally earn from various EAs. It is evident from the Table 3 that major income $(23.75 \%)$ of both groups of women came from home gardening. The next highest share $(20.7 \%)$ came from poultry management. Accordingly, goat rearing, cattle rearing and non-agricultural activities contribute in the personal income of the respondent women. On the other hand, respondent women earn smallest $(0.15 \%)$ amount from pre-harvest activities. However, the above Table 3 shows that there is a significant difference in income earning of the women of NGO and Non-NGO types. Without an exception of post-harvest activities NGO women earn higher income from all the sources. This due to the reason that NGO women received various skill developments training like home gardening, poultry and livestock management, aquaculture, handicrafts making, tailoring etc. which is significantly increased their capabilities. 
Table 3: Women's personal income from various EAs (average and unit in '000' Taka)

\begin{tabular}{|c|c|c|c|c|c|c|c|c|c|c|c|}
\hline $\begin{array}{l}\text { Types of } \\
\text { women }\end{array}$ & $\begin{array}{l}\text { Pre- } \\
\text { harvest } \\
\text { activities }\end{array}$ & $\begin{array}{l}\text { Post- } \\
\text { harvest } \\
\text { s activities }\end{array}$ & $\begin{array}{l}\text { Home } \\
\text { gardening }\end{array}$ & $\begin{array}{l}\text { Poultry } \\
\text { management }\end{array}$ & $\begin{array}{l}\text { Goat } \\
\text { rearing }\end{array}$ & $\begin{array}{l}\text { Cattle } \\
\text { rearing }\end{array}$ & $\begin{array}{l}\text { Aqua- } \\
\text { culture } \\
\text { activities }\end{array}$ & $\begin{array}{l}\text { Marketing } \\
\text { activities }\end{array}$ & $\begin{array}{l}\text { Wage } \\
\text { labour }\end{array}$ & $\begin{array}{l}\text { Non-argil. } \\
\text { activities }\end{array}$ & $\begin{array}{l}\text { Total } \\
\text { income }\end{array}$ \\
\hline NGO women & $\begin{array}{c}1.00 \\
(0.26)\end{array}$ & $\begin{array}{l}10.30 \\
(2.70)\end{array}$ & $\begin{array}{c}83.28 \\
(21.87)\end{array}$ & $\begin{array}{c}71.47 \\
(18.77)\end{array}$ & $\begin{array}{c}67.87 \\
(17.83)\end{array}$ & $\begin{array}{c}69.00 \\
(18.13)\end{array}$ & $\begin{array}{c}2.50 \\
(0.66)\end{array}$ & $\begin{array}{l}7.50 \\
(1.97)\end{array}$ & $\begin{array}{l}17.5 \\
(4.6)\end{array}$ & $\begin{array}{c}50.25 \\
(13.20)\end{array}$ & 380.67 \\
\hline Non-NGO women & $\begin{array}{c}0.00 \\
(0.00)\end{array}$ & $\begin{array}{l}63.95 \\
(21.94)\end{array}$ & $\begin{array}{l}76.35 \\
(26.20)\end{array}$ & $\begin{array}{r}67.70 \\
(23.23\end{array}$ & $\begin{array}{r}15.20 \\
(5.22)\end{array}$ & $\begin{array}{c}35.30 \\
(12.11)\end{array}$ & $\begin{array}{c}1.70 \\
(0.58)\end{array}$ & $\begin{array}{c}1.50 \\
(0.51)\end{array}$ & $\begin{array}{c}0.0 \\
(0.0)\end{array}$ & $\begin{array}{c}29.75 \\
(10.21)\end{array}$ & 291.45 \\
\hline All average & $\begin{array}{l}1.00 \\
(0.15)\end{array}$ & $\begin{array}{l}74.25 \\
(11.05)\end{array}$ & $\begin{array}{l}159.63 \\
(23.75)\end{array}$ & $\begin{array}{l}139.17 \\
(20.70)\end{array}$ & $\begin{array}{c}83.07 \\
(12.36)\end{array}$ & $\begin{array}{l}104.30 \\
(15.52)\end{array}$ & $\begin{array}{c}4.20 \\
(0.62)\end{array}$ & $\begin{array}{c}9.00 \\
(1.34)\end{array}$ & $\begin{array}{l}17.5 \\
(2.6)\end{array}$ & $\begin{array}{c}80.00 \\
(11.90)\end{array}$ & 672.12 \\
\hline
\end{tabular}

*: Values in the parentheses indicate percentage

Source: Authors' survey

Thus, they take part these types activities more perfectly than previous and earn more in compare to their counter part Non-NGO women. On the other hand due to economic solvency and good social status of the family Non-NGO women do not work as wage labour. While due to temporary or permanent financial and food crisis a few of the NGO women earn by working as a wage labour and contribute in household income.

Another important objective of the study was to explore the factors that can significantly influence women's extent of participation in EAs. For this purpose multiple regression analysis was done and the estimated result of the regression analysis shows that five factors can combinedly influence $59.0 \%$ (Adjusted $\mathrm{R}^{2}=0.590 * *$ and $\mathrm{F}=22.796^{* *}$ ) women's extent of participation in various EAs. Consequently, the final equation of multiple regression is:

$$
\begin{aligned}
& \mathrm{Y}=8.498+0.346 \mathrm{CRED}+0.241 \text { TRAIN }+(-0.214) \mathrm{EDU} \\
& \begin{array}{lll}
(9.119) & (3.241 * *) \quad(2.991 * *) \quad(-2.687 * *)
\end{array} \\
& +(-0.142) \mathrm{AGE}+0.101 \mathrm{INSPART} \\
& (-2.041 *) \quad(1.080 *) \\
& * *=\text { Indicates significant at } 1 \% \text { level } \\
& *=\text { Indicates significance at } 5 \% \text { level }
\end{aligned}
$$

Among the five factors micro-credit, training and institutional participation of the women have significant positive influence on women's extent of participation in EAs. A report of the United Nations ${ }^{[9]}$ also supports that through receiving micro-credit Bangladeshi rural women is getting independent sources of EAs and income outside home and it tends to reduce their economic dependency on husbands and thus help to enhance their autonomy in the family. While, educational level shows significant negative relationships. This is due to the reason that highly educated women are not likely intend to participate in hard physical woks. Likewise education it found in the results that age is also negatively related with women's extent of participation in EAs. Whereas, monitoring by the credit provider NGOs don't have any significant influence on women's extent of participation in EAs.

Effects of women's participation in EAs on their household income: Various dimensions (i.e., material, cognitive and relational) are directly involved with women empowerment process. From launching of the micro-credit programs in Bangladesh a huge number of micro-credit NGOs took initiative to mobilize and organize women at the grass root level and provide them access to supportive services to improve their empowerment both in family and in society (also mentioned in Figure 1). Grameen Bank (one of the leading micro-credit NGO in Bangladesh) claimed that through micro-credit programme rural women have attained more power and freedom than previous ${ }^{[10]}$. However, we decisively believe that women's empowerment depends rather on their capabilities to earn by themselves and contribute in the household income.

The result of regression analysis indicates that $63.9 \%$ (Adjusted $\mathrm{R}^{2}=0.639^{* *}$ ) of the variance in the respondent's household income could be explained by women's personal income through participation in various EAs. The estimated regression function is $\mathrm{Y}$ $=13.98+4.245$ WPI (with $\mathrm{t}$ value $9.16^{* *}$ ) and that also shows a linear relationship (Fig. 2).

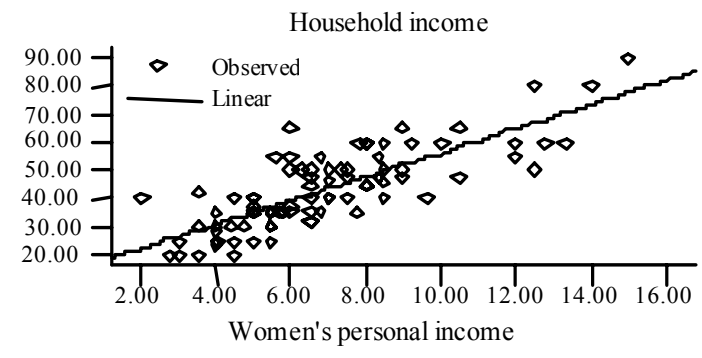

Fig. 2: Contribution of women's personal income in household income 
The findings of the study is supported by a study of $\mathrm{FAO}^{[2]}$ and $\mathrm{CPD}^{[8]}$ that also reported that women in Bangladesh are contributing considerably in household income through farm and homestead production and wage labor, treated as the important EAs for the rural women.

Another study of Rahman and Naoroze also reported that a project named Development of Sustainable Aquaculture Project (DSAP) launched in Bangladesh in 2000 for the development of the fisheries sector which was funded by the USAID (United States Agency for International Development) and the project is implemented by the World Fish Center, a member of CGIAR (Consultative Group on International Agricultural Research $)^{[7]}$. Their findings noticed that the women beneficiaries of this project are contributing to some extent in their household income through participation in aquaculture activities in small ponds and as well as rice cum fish culture.

Role of women in the decision making process: A traditional patriarchal society system exists in Bangladesh where a household's decisions are usually made by the male members of the family. One of the important objectives of the study was to learn role of rural women in family decision making process. However, unfortunately it is evident from Table 4 that with few exceptions the participation of the women in the family decision making process is poor (within 10$40 \%)$. It is revealed from the Table 4 that the highest portion $(60.87 \%)$ of the respondent women make decisions on cattle, goat and poultry rearing which ranked first among all of the issues. The findings of Paul and Sadullah also support the same findings. Subsequently, home gardening, selection of crop and variety and children's education ranked second, third and fourth position respectively ${ }^{[11]}$.
It is apparent from Table 4 that with few exceptions the majority of the man takes decisions alone rather than consulting with woman. There is also significant difference among NGO and Non-NGO women to take part in decision making process in several issues. The subsequent Table 4 clearly exhibits that NGO women's participation is significantly more in the case of taking decision regarding buying and selling of land, children's education, home gardening and cattle, goat \& poultry rearing.

The result of regression analysis indicates that 47.7 percent (Adjusted $\mathrm{R}^{2}=0.477 * *$ ) of the variance in the decision making role of women could be explained by women's personal income from various EAs. The estimated regression function is $\mathrm{Y}=-0.015+0.558$ WPI and that also shows a linear relationship (Fig. 3).

A study of Bangladesh by Pitt and his co-researchers ${ }^{[12]}$ reported that woman who participate in micro-credit are take a greater role in household decision making, have greater access to financial, economic, and social resources, and enjoy greater mobility. They further explained that rural women in Bangladesh are participating in various EAs after taking loan from micro-credit NGOs thus

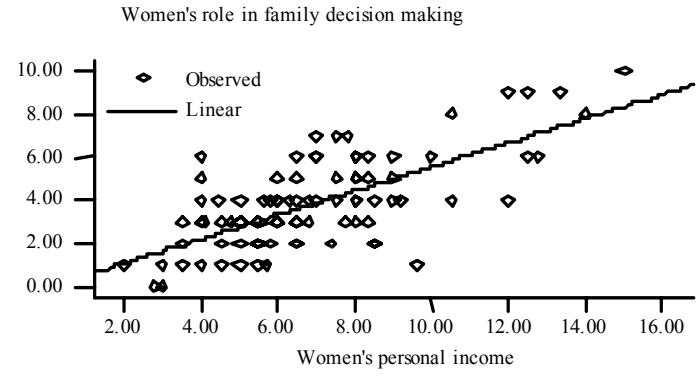

Fig. 3: Contribution of women's personal income on their role in family decision making

Table 4: Participation of farm women in the decision making process and their comparison between two groups

\begin{tabular}{|c|c|c|c|c|c|c|c|c|c|c|}
\hline \multirow[t]{3}{*}{ Issues } & \multirow{3}{*}{$\begin{array}{l}\text { No. of } \\
\text { women taking } \\
\text { part in } \\
\text { the decision } \\
\text { making process }\end{array}$} & \multirow[b]{3}{*}{$(\%)$} & \multirow{3}{*}{$\begin{array}{l}\text { Rank } \\
\text { order }\end{array}$} & \multicolumn{6}{|c|}{ Women in the decision making process } & \multirow[b]{3}{*}{$\chi^{2}$} \\
\hline & & & & \multicolumn{3}{|c|}{ NGO women } & \multicolumn{3}{|c|}{ Non- NGO women } & \\
\hline & & & & WA & MA & Com & WA & MA & Com & \\
\hline Selection of crop and variety & 36 & 39.13 & 3 & 15 & 23 & 8 & 9 & 33 & 4 & $4.62^{\mathrm{NS}}$ \\
\hline Tree plantation & 34 & 36.96 & 5 & 17 & 25 & 4 & 7 & 33 & 6 & $5.66^{\mathrm{NS}}$ \\
\hline Home gardening & 54 & 58.70 & 2 & 15 & 22 & 9 & 9 & 16 & 21 & $7.24 *$ \\
\hline Cattle, goat and poultry rearing & 56 & 60.87 & 1 & 17 & 13 & 16 & 7 & 23 & 16 & $6.92 *$ \\
\hline Crop, cattle, goat and poultry selling & 18 & 19.57 & 8 & 5 & 33 & 8 & 3 & 41 & 2 & $4.96^{\mathrm{NS}}$ \\
\hline Spending money & 10 & 10.87 & 10 & 7 & 38 & 1 & 1 & 44 & 1 & $4.94^{\mathrm{NS}}$ \\
\hline Buying of necessities & 22 & 23.91 & 7 & 12 & 33 & 1 & 6 & 37 & 3 & $3.22^{\mathrm{NS}}$ \\
\hline Children's education & 34 & 36.96 & 4 & 22 & 21 & 1 & 10 & 35 & 1 & $8.00 *$ \\
\hline Buying and selling of land & 30 & 32.61 & 6 & 13 & 28 & 5 & 3 & 34 & 9 & $9.41 * *$ \\
\hline Family budgeting & 14 & 15.22 & 9 & 9 & 38 & 3 & 3 & 40 & 3 & $0.46^{\mathrm{NS}}$ \\
\hline
\end{tabular}

Note: WA: Women alone, MA: Male alone, Com: Combined, NS: Not significant, *: Significance at $5 \%$ level, **: Significance at $1 \%$ level

Source: Authors' analysis 
they are being capable to contribute in household income which is improving their status in the family even some cases they are playing active role in taking decision regarding some family issues. Thus it is proved that due to participation in EAs women in the rural areas are contributing in household income that has also improved their role in family decision making than before.

\section{CONCLUSIONS}

From the above discussion it has been learnt that despite their poor socio-economic status the rural women of Gaibandha district actively participate in various EAs especially livestock \& poultry management, various post-harvest operations and few non-agricultural activities. Based on the results of the study it can be concluded that due to participation in various EAs rural women in Bangladesh are earning some cash and contributing to some extent in their household's income. Thus, it is of utmost important to formulate an appropriate strategy for increasing their participation in EAs. However, their input in the family decision making process is still remains far bellow the expectation. The findings of the study also show that the NGO women's participation is relatively better than the Non-NGO women both in EAs and family decision making process. It could be concluded from this result that the involvement of women in micro-credit NGOs are improving their levels of participation in EAs and family decision making process but not by as much as was hoped. So, the role of these micro-credit NGOS has found to some extent positive in motivating the rural women to participate more in EAs as well as in family decision making process. Therefore, it is very essential to take immediate steps to involve the women energetically in the mainstream development through providing them various training like home gardening, cattle, goat \& poultry management and other income generating activities by the micro-credit NGOs and GOs. These types of training might increase their knowledge and skill and may create opportunities of employment and increase income earning for improving their participation in the family decision making process which eventually empowered the rural women in their family as well as in the society.

\section{REFERENCES}

1. Bangladesh Bureau of Statistics (BBS), 2006. Statistical Year Book of Bangladesh, Bangladesh Bureau of Statistics, Planning Division, Ministry of Planning, Government of the People's Republic of Bangladesh, available http://www.bbs.gov.bd/dataindex/yearbook_06.pdf, available at, February 01, 2008.
2. FAO, 2000. "Women in Agriculture, Environment and Rural Production", Fact Sheet Bangladesh, available at, ftp://ftp.fao.org/sd/sdw/sdww/bgd.pdf, on March 28, 2008.

3. Asian Development Bank (ADB), 2001. "Women in Bangladesh", available at http:/www.adb.org/Documents/Books/Country_Br iefing_Papers/Women_in_Bangladesh/chap2.pdf, on February15, 2008.

4. UNDP, 2006. Human Development Reports-2005. United Nations Development Program, Washington DC, available at, http://hdr.undp.org/en/media/HDR06complete.pdf, on January 07, 2008.

5. Hossain, M., 1998. Credit for Alleviation of Rural Poverty: The Grameen Bank of Bangladesh. In: IFPRI Research Report 65, International Food Policy Research Institute, Washington DC, available at, http://www.ifpri.org/pubs/abstract/65/rr65.pdf, on January 14, 2008.

6. Department of Agricultural Extension (DAE), 1999. Agricultural Extension Manual. Department of Agricultural Extension, Ministry of Agriculture, Government of the People's Republic of Bangladesh, available at, http://dae.gov.bd/Pdf\%20forms/Book/Extension Mannual_Chapt1.pdf, on March 20, 2008.

7. Rahman, M.H. and K. Naoroze, 2007. Women empowerment through participation in aquaculture: Experience of a large-scale technology demonstration project in Bangladesh. J. Soc. Sci., 3(4): 164-171, available at, http://www.scipub.org/fulltext/jss/jss34164-

171.pdf, on February 01, 2008.

8. Centre for Policy Dialogue (CPD), 2004. Nature and impact of women's participation in economic activities in rural Bangladesh. In: Centre for Policy Dialogue (CPD) and International Rice Research Institute (IRRI) Policy Brief 7, available on January $16, \quad 2008 \quad$ In: http://www.cpdbangladesh.org/publications/cpdiri/ cpdiri_7.

9. United Nations (UN), 2004. "Implementation of the first United Nations Decade for the Eradication of Poverty (1997-2006) and preparations for the International Year of Micro-credit, 2005”, available at, http://www.yearofmicrocredit.org/docs/N0449915. pdf, on March 05, 2008. 
10. Grameen Bank (GB), 1998. Bangladeshi Women and the Grameen Bank, available at, http://www.idrc.ca/en/ev-5066-201-1-

DO TOPIC.html.

11. Paul, D.C. and M. Sadullah, 1991. Role of women in homestead of small farm category in an area of Jessore, Bangladesh. Bangladesh J. Anim. Sci., 3: 31-46, available

at, http://www.cipav.org.co/lrrd//rrd3/2/bang1.htm, on April 10, 2008.
12. Pitt, M., S. Khandker, and J. Cartwright. 2003. "Does Micro-Credit Empower Women? Evidence from Bangladesh." Policy Research Working Paper 2998, World Bank, Washington, DC, and In: Bangladesh Development Series, Paper No. 11

"Economics and Governance of Nongovernmental Organizations in Bangladesh, available at, http://siteresources.worldbank.org/BANGLADESHEXT N/Resources/NGOreport_Dev_Series.pdf, on January 16 2008. 